\title{
Four new species of Thouarella (Anthozoa: Octocorallia: Primnoidae) from Antarctic waters
}

\author{
REBECA ZAPATA-GUARDIOLA and PABLO J. LÓPEZ-GONZÁLEZ \\ Departamento de Fisiología y Zoología, Facultad de Biología, Universidad de Sevilla, Reina Mercedes 6, 41012-Sevilla, \\ Spain.E-mail: rebzapgua@alum.us.es; pjlopez@us.es
}

\begin{abstract}
SUMMARY: Four new Antarctic species of the genus Thouarella, all of them belonging to the subgenus Thouarella, are described and illustrated from material collected at the South Georgia and the South Sandwich Islands, and off Atka Bay (eastern Weddell Sea) on the Polarstern cruises ANT XIX/5 (LAMPOS), and ANT XXIV/2 (ANDEEP-SYSTCO). The study of our new taxa allows us to describe a wider variation in the number of the distal cycles of polyp scales, as well as the existence in the genus (and subgenus) of additional species with planar colonial morphologies. The new species are compared with their closest congeners.
\end{abstract}

Keywords: Cnidaria, Octocorallia, Primnoidae, Antarctica, Thouarella.

RESUMEN:Cuatronuevas especies de Thouarella(Anthozoa:Octocorallia:Primnoidae) de aguasAntárticas.-En este trabajo se describen e ilustran cuatro nuevas especies del género Thouarella, todas ellas pertenecientes al subgénero Thouarella, recolectadas durante las campañas ANT XIX/5 (LAMPOS) y ANT XXIV/2 (ANDEEP-SYSTCO) a bordo del buque oceanográfico Polarstern. Estas campañas antárticas fueron realizadas en las islas Georgia del Sur, las islas Sandwich del Sur y en la Bahía Atka (al este del mar de Weddell). El estudio de estos nuevos taxones nos permite describir una mayor variabilidad en el número de ciclos distales de escleritos presentes en los pólipos, así como la presencia adicional en el género (y en el subgénero) de especies con morfología colonial plana. Las nuevas especies son comparadas con sus congéneres más cercanos.

Palabras clave: Cnidaria, Octocorallia, Primnoidae, Antártida, Thouarella.

\section{INTRODUCTION}

Thouarella Gray, 1870 is one of the most specious primnoid genera (Kükenthal, 1924; Cairns, 2006) and the best represented in Antarctic and subAntarctic waters.

According to the last papers describing new species and giving an overall view of this genus (Cairns, 2006 and Cairns and Bayer, 2009), at least 29 species could be considered valid, many of them in need of revision. According to the geographic distribution of the species of Thouarella, there are species in all oceans and eight of them have been reported in the Southern Ocean: Thouarella striata Kükenthal, 1907, T. pendulina (Roule, 1908), T. longispinosa Kükenthal, 1912 and T. crenelata Kükenthal, 1908 in Antartica, and T. affinis Wright and Studer, 1889, T. koellikeri Wright and Studer, 1889 and T. brucei Thomson and Ritchie, 1906 in the sub-Antarctic region. In both regions we find $T$. variabilis Wright and Studer, 1889, T. antarctica (Valenciennes, 1846) and T. chilensis Kükenthal, 1907. However, most species are only known from a few localities apart from their type locality.

Species belonging to this genus are divided into four subgenera, Euthouarella, Epithouarella, Para- 
thouarella (see diagnoses for all in Kükenthal, 1915, 1919,1924 ) and Diplocalyptra (see diagnoses in Kinoshita, 1908 and Cairns and Bayer, 2009). As the subgenus Parathouarella includes the type species of the genus (T. antarctica), it is more appropriate to use the name Thouarella also as a subgeneric name in considering that group of Thouarella species (Cairns, 2006). In the distinction of the different subgenera, characters from marginal scale morphology are mainly used, such as the presence or absence of a spine on their distal part, in addition to the distribution of the polyps on branches and branchlets (Kükenthal, 1924).

During the Antarctic cruises ANT XIX/5 and ANT XXIV/2, a significant amount of Thouarella s.l. specimens were collected. Among this material were a number of specimens belonging to the subgenus Thouarella. Some of the characters present in the studied material increase the variation of the number of the distal scales and the shape of the colonies. The study of these colonies allows us to propose four new species in the subgenus.

\section{MATERIALS AND METHODS}

The material studied was collected on the RV Polarstern cruises ANT XIX/5 (LAMPOS, Latin American Polarstern Study, 3 April to 5 May 2002), and XXIV/2 (ANDEEP-SYSTCO, Antarctic Benthic Deep-Sea Biodiversity System Coupling, 28 November 2007 to 4 February 2008), all sponsored by the Alfred Wegener Institut für Polar- und
Meeresforschung (Bremerhaven) under the auspices of the SCAR (Scientific Committee for Antarctic Research).

Octocoral colonies were collected using an Agassiz trawl or a bottom trawl along the South Georgia Ridge and the Atka Bay (Fig. 1). The octocorals were fixed in $10 \%$ buffered formalin onboard ship and then transferred to $70 \%$ ethanol in the laboratory. Fragments from different parts of the colonies were prepared for study by SEM, employing the usual methodology described previously by several authors (e.g. Bayer and Stefani 1989; Alderslade 1998), and permanent mounts were made for light microscopy observation. All sclerite size measurements and illustrations are from the holotypes. The colony and sclerite terminology herein mainly follows Bayer et al. (1983). The material studied has been deposited at the Zoologisches Institut und Zoologisches Museum, Hamburg, Germany (ZIZMH); the National Museum of Natural History, Smithsonian Institution, Washington, D.C. (USNM); and the Anthozoan Reference Collection of the research group "Biodiversidad y Ecología de Invertebrados Marinos" of the University of Seville (BEIM).

\section{RESULTS}

Family PRIMNOIDAE Gray, 1858

Genus Thouarella Gray, 1870

Subgenus Thouarella Gray, 1870

Nominal species in the subgenus Thouarella

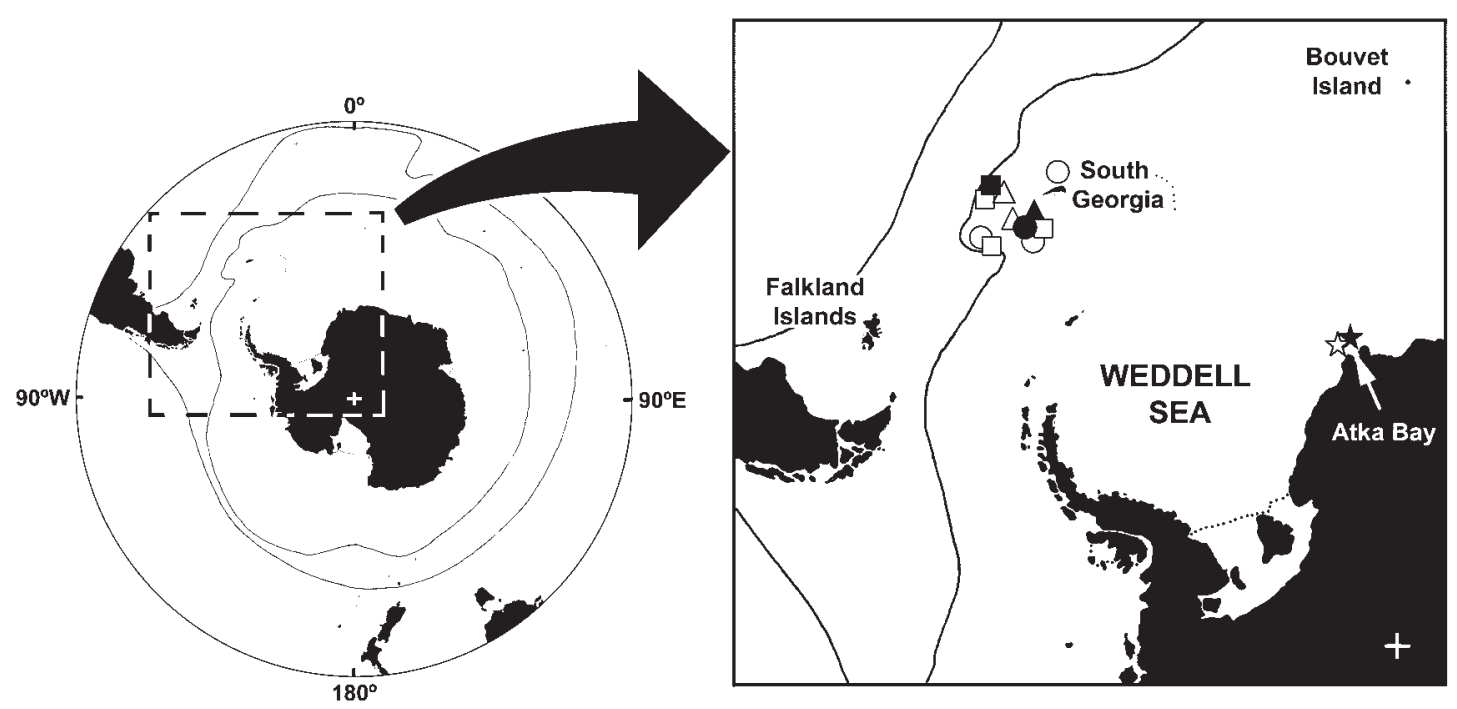

FIG. 1. - Known distribution of Thouarella species described in this paper: triangle, Thouarella bayeri $\mathrm{n}$. sp.; circle, Thoaurella sardana $\mathrm{n}$. sp.; square, Thouarella undulata $\mathrm{n}$. sp.; star, Thouarella andeep n. sp. Solid symbols represent the respective type localities. 
Thouarella (T.) antarctica (Valenciennes, 1846)

Thouarella (T.) koellikeri Wright and Studer, 1889

Thouarella (T.) variabilis Wright and Studer, 1889

Thouarella (T.) brucei Thomson and Ritchie, 1906

Thouarella (T.) striata Kükenthal, 1907

Thouarella (T.) versluysi Kükenthal, 1907

Thouarella (T.) clavata Kükenthal, 1908

Thouarella (T.) pendulina (Roule, 1908)

Thouarella (T.) hicksoni Thomson, 1911

Thouarella (T.) alternata Nutting, 1912

Thouarella (T.) recta Nutting, 1912

Thouarella (T.) superba (Nutting, 1912)

Thouarella (T.) bipinnata Cairns, 2006

Thouarella (T.) diadema Cairns, 2006

Thouarella (T.) bayeri Zapata-Guardiola and LópezGonzález, n. sp.

Thouarella (T.) sardana Zapata-Guardiola and López-González, n. sp.

Thouarella (T.) undulata Zapata-Guardiola and López-González, n. sp.

Thouarella (T.) andeep Zapata-Guardiola and López-González, n. sp.

\section{Thouarella (Thouarella) bayeri n. sp.} (Figs. 2A-B, 3-4)

Examined material. Holotype: ZIZMH C11738, ANT XIX/5, stn PS61/164-01, 53 23.80'S, 42 $42.03^{\circ} \mathrm{W}$, west South Georgia, Antarctica, 312.5 to $321.6 \mathrm{~m}$ depth, 9 April 2002. Paratypes: ZIZMH $\mathrm{C} 11739$, with the same sampling data as the holotype, two colonies and two fragments. USNM 1123419 , with the same sampling data as the holotype, one colony and two fragments. Additional mate-

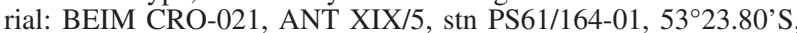
$42^{\circ} 42.03^{\prime} \mathrm{W}$, west South Georgia, Antarctica, 312.5 to $321.6 \mathrm{~m}$ depth, 9 April 2002, two colonies (one of them without holdfast) and two fragments. BEIM CRO-022, ANT XIX/5, stn PS61/167-01, $53^{\circ} 23.68^{\prime} \mathrm{S}, 42^{\circ} 42.23^{\prime} \mathrm{W}$, west South Georgia, Antarctica, 306.0 to $342.7 \mathrm{~m}$ depth, 9 April 2002, two fragments.

Description of the holotype. Colony uniplanar (Fig. 2A), $9.6 \mathrm{~cm}$ in height and $4 \mathrm{~cm}$ in width, dichotomously branched, internodes about $6-27 \mathrm{~mm}$ in length, unbranched terminal twigs up to $26 \mathrm{~mm}$. Axis bronze in colour, stiff and firmly attached to hard substrate by a white, calcareous, discoidal holdfast, basal axis diameter of $1.3 \mathrm{~mm}$ and $21 \mathrm{~mm}$ height until the first division.

Polyps perpendicular to stem (Fig. 2B), present on main stem and branches in a roughly alternating arrangement, occasionally opposite (i.e. paired), with little tendency toward pairs or whorls, 9-12 polyps per cm. Polyps (Fig. 3C) relatively short, cylindrical to club-shaped distally, about $1.6-2.4 \mathrm{~mm}$ in height and 0.47-0.91 $\mathrm{mm}$ in diameter without including sclerite spines, which may extend consider- ably beyond the operculum. Polyp body with seven longitudinal rows of scales, 4-5 transversal rows of scales on each longitudinal abaxial row overlapping one another.

Second accessory opercular scales in variable number, from absent to four (rarely seven), stickshaped. Where present, on the inner surface of first accessory opercular scales very close together.

First accessory opercular scales in numbers of eight, arranged in two alternate cycles of four scales: inner cycle (Fig. 4A) with small, 0.27-0.41 x 0.09$0.14 \mathrm{~mm}$, narrow, stick-shaped tentacular scales; outer cycle (Fig. 4B) with bigger, 0.22-0.42 x 0.14$0.22 \mathrm{~mm}$, broad, arrowhead-like scales. Proximal inner surfaces tuberculate, covering about one third in length, distal inner surface smooth, without keel. Outer surface quite smooth. Basal margin with digitate processes, free margin finely serrated.

Opercular scales, 0.62-1.06 x 0.41-0.54 mm, arranged in two alternate cycles of four scales: inner cycle (Fig. 4C) with blunt tips and squarish base; outer cycle (Fig. 4D) with isosceles-shaped scales. Inner surface like that in accessory opercular scales. Outer surface with radial granules from nucleus on proximal portion. Free margin finely serrated.

Marginal scales, seven (eight) in number (Fig. 4E), basal part of scale equilateral triangle-shaped projecting a long thorn, round in section, 1.1-1.83 $x$ 0.52-0.83 $\mathrm{mm}$ in length (including thorn), thorn more than three-quarters of total sclerite length, with numerous longitudinal ridges on all sides. Outer surface with granules radially arranged from nucleus on proximal portion. Free margin serrated, proximal margin with digitate processes.

Remaining body scales (Fig. 4F) with tendency to circular or oval shape, $0.38-0.63 \mathrm{~mm}$ in maximum length. Inner surface completely tuberculate, outer surface with granules radiating from nucleus on proximal portion. Free margin finely serrated, basal margin with digitate processes. Submarginal scales with or without a short distal projection (Fig. 3E).

Coenenchyme scales (fig. 4G) more diverse in shape, ranging from round to irregular elongated polygons, $0.18-0.45 \mathrm{~mm}$ in maximum length. Surface with similar ornamentation to body scales. Margin quite smooth, some serrated, or with digitate processes.

Variations. The general colonial structure of the paratypes and additional examined material is quite similar to that of the holotype. Colonies reach up to 


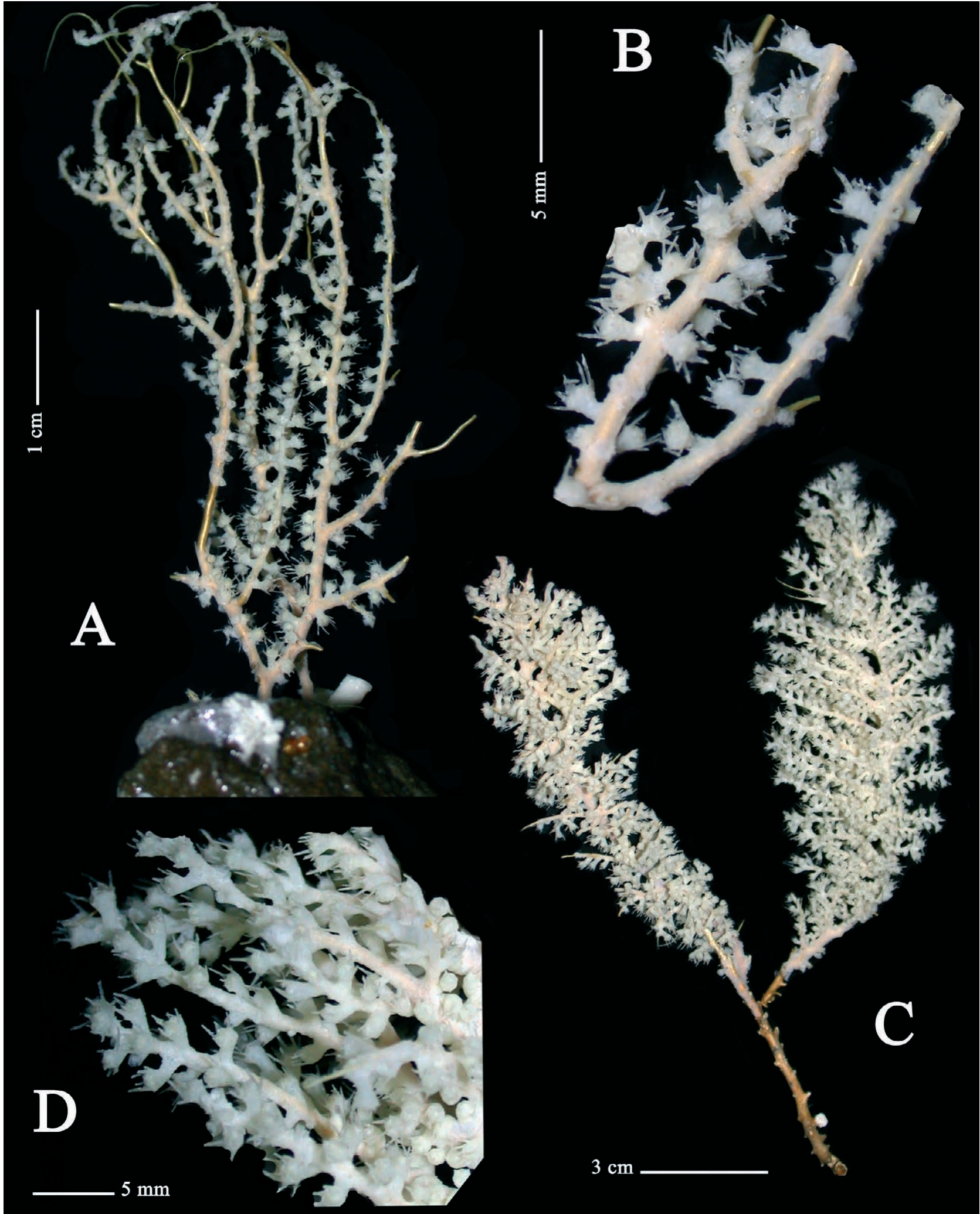

FIG. 2. - Thouarella bayeri n. sp., holotype ZIZMH C11738: A, whole colony; B, detail of a branchlet. Thoaurella sardana n. sp., holotype ZIZMH C11740: C, whole colony; D, detail of a branchlet. 

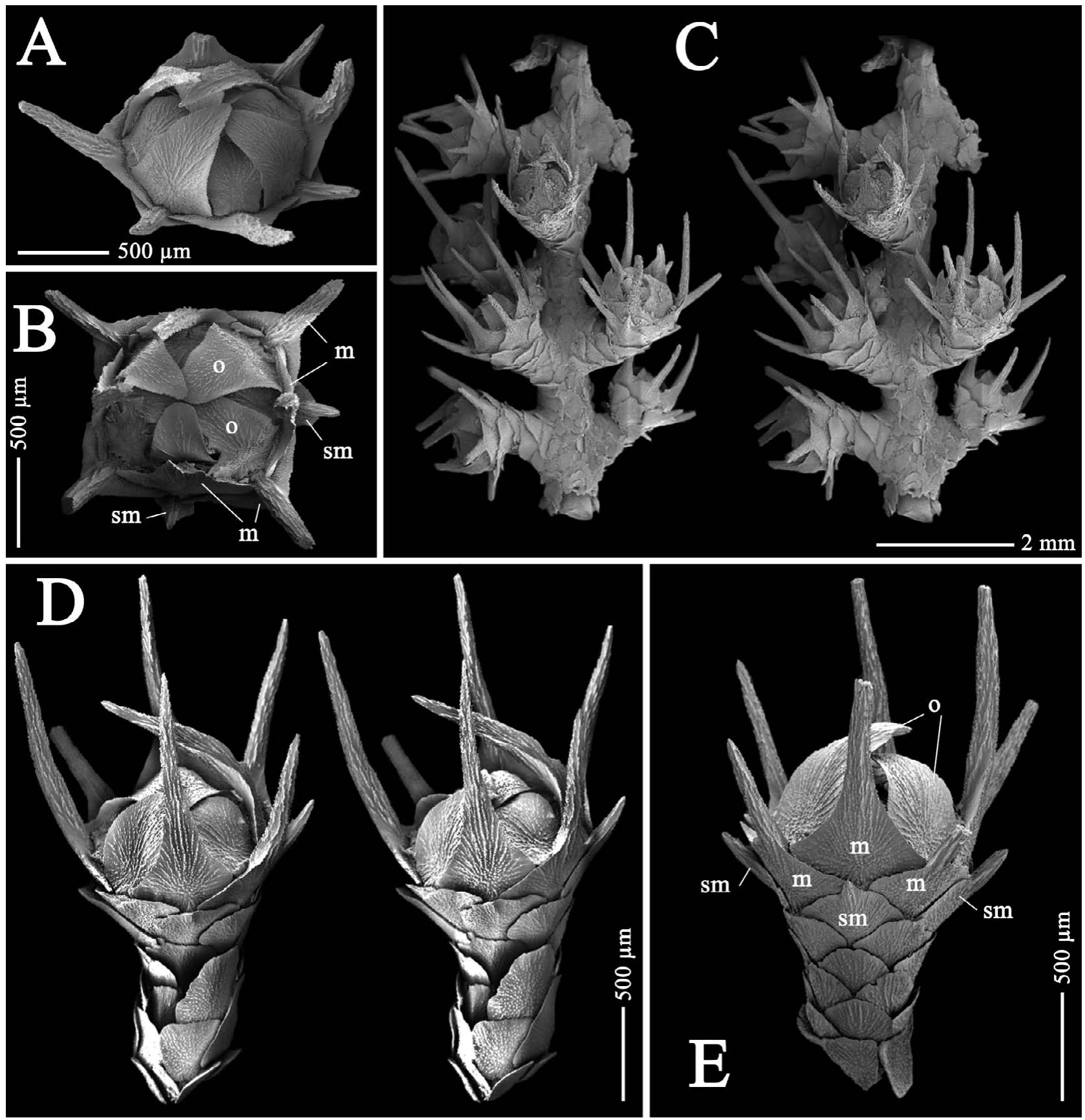

FIG. 3. - Thouarella bayeri n. sp., holotype ZIZMH C11738: A and B, polyps in oral view; C, detail of branchlet, stereo pair; D, polyps on latero-adaxial view, stereo pair; E, polyps in lateral view. Abbreviations: o, opercular scales; m, marginal scales; sm, submarginal scales.

$8 \mathrm{~cm}$ in height and $5 \mathrm{~cm}$ in width. The ramification pattern is somewhat elongated or broad. The main stem (before the first dichotomic division) is 6-13 $\mathrm{mm}$ in length. The polyp form and distribution are as in the holotype. Second accessory opercular scales can vary from absent to four in number as in the holotype. The outer cycle of opercular scales in some colonies or fragments of paratypes are less pointed and isosceles-shaped
Geographic and bathymetric distribution. At present, Thouarella bayeri $\mathrm{n}$. sp. is known only from west of South Georgia Island, Antarctica (Fig. 1), between 306 and $342.7 \mathrm{~m}$ in depth.

Etymology. The specific name bayeri is chosen in honour of Prof. F.M. Bayer, in recognition of his valuable contributions to the knowledge of Octocorallia taxonomy. 


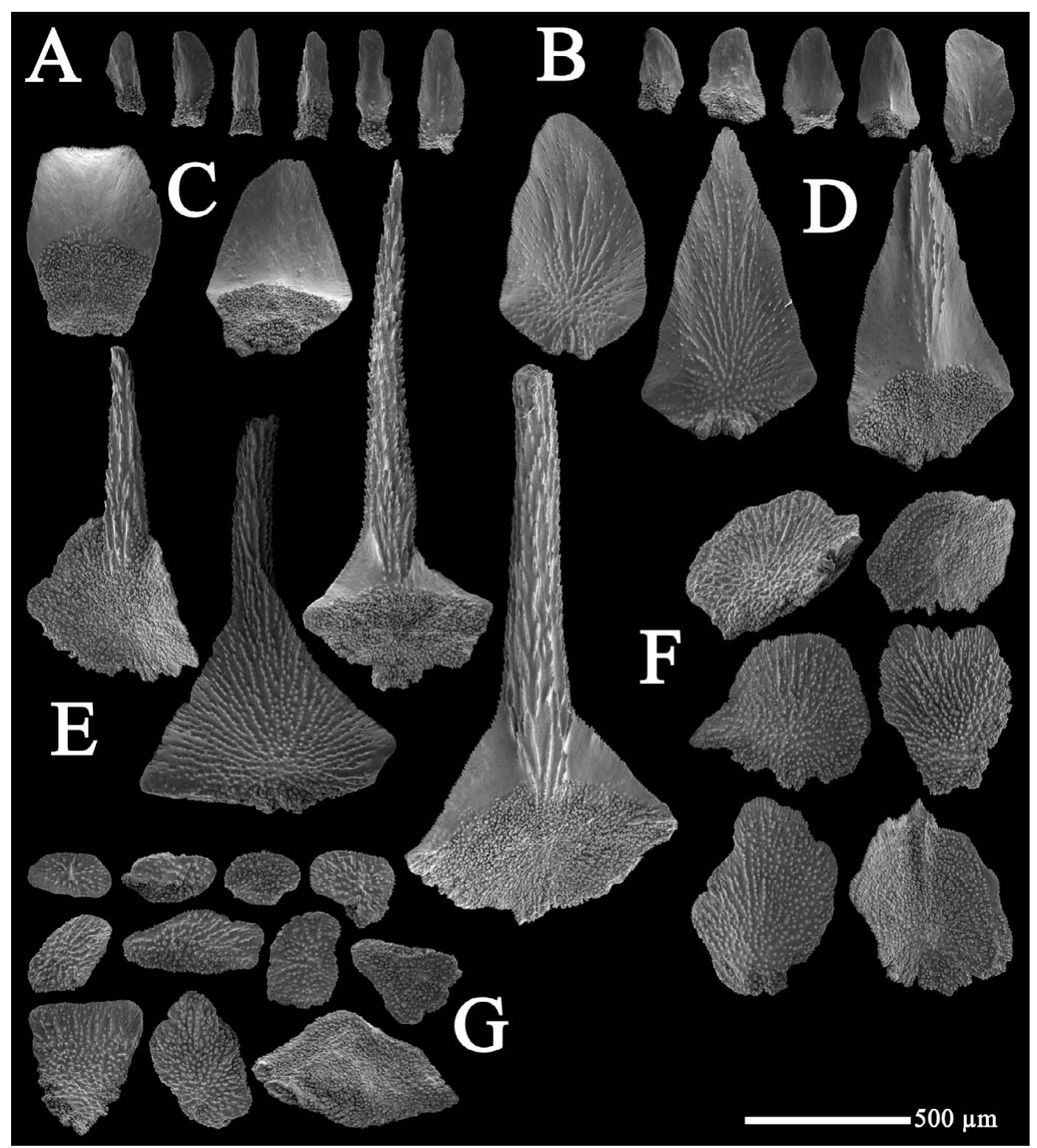

FIG. 4. - Thouarella bayeri n. sp., holotype ZIZMH C11738: First accessory opercular scales from inner (A) and outer (B) alternate cycle. Opercular scales from inner (C) and outer (D) alternate cycle. Marginal scales (E). Body scales. (F). Coenenchymal scales (G).

Thouarella (Thouarella) sardana $\mathrm{n} . \mathrm{sp}$. (Figs. 2C-D, 5-7)

Examined material. Holotype: ZIZMH C11740, ANT XIX/5, stn PS61/164-01, 532 $23.80^{\prime} \mathrm{S}, 42^{\circ} 42.03^{\prime} \mathrm{W}$, west of South Georgia, Antarctica, 312.5 to $321.6 \mathrm{~m}$ depth, 9 April 2002. Paratypes: ZIZMH C11741, with the same sampling data as the holotype, three colonies and seven fragments. USNM 1123420, with the same sampling data as the holotype, two colonies. Additional material: BEIM CRO-

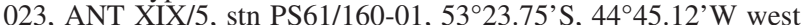
of South Georgia, Antarctica, $434 \mathrm{~m}$ depth, 9 April 2002, one colony. BEIM CRO-024, ANT XIX/5, stn PS61/174-01, 54²4.47'S, $35^{\circ} 36.81^{\prime} \mathrm{W}$ north of South Georgia, Antarctica, $278 \mathrm{~m}$ depth, 11 April 2002, one fragment.

Description of the holotype. Colony bottlebrush (Fig. 2C), $15.3 \mathrm{~cm}$ in length, with two main branches from the main stem, probably part of a larger colony. One of the branches $12.2 \mathrm{~cm}$ in height and $4.9 \mathrm{~cm}$ in width, and the other one $10.4 \mathrm{~cm}$ in height and $3 \mathrm{~cm}$ in width; stiff branchlets (Fig. 2D) simple or bifurcate on their bases, about $1-2.5 \mathrm{~cm}$ in length. Axis bronze in colour, stiff. Basal axis diameter of 2.2 $\mathrm{mm}$ and $35 \mathrm{~mm}$ height until the first main branches.

Polyps almost perpendicular to stem (Fig. 2D, 5C), present on main stem and branches, arranged in a spiral (Fig. 5C), occasionally opposite on proximal part of branches, with no tendency toward pairs or whorls. 9-10 polyps per cm. Polyps (Fig. 5) relatively short, cylindrical to club-shaped distally; about 

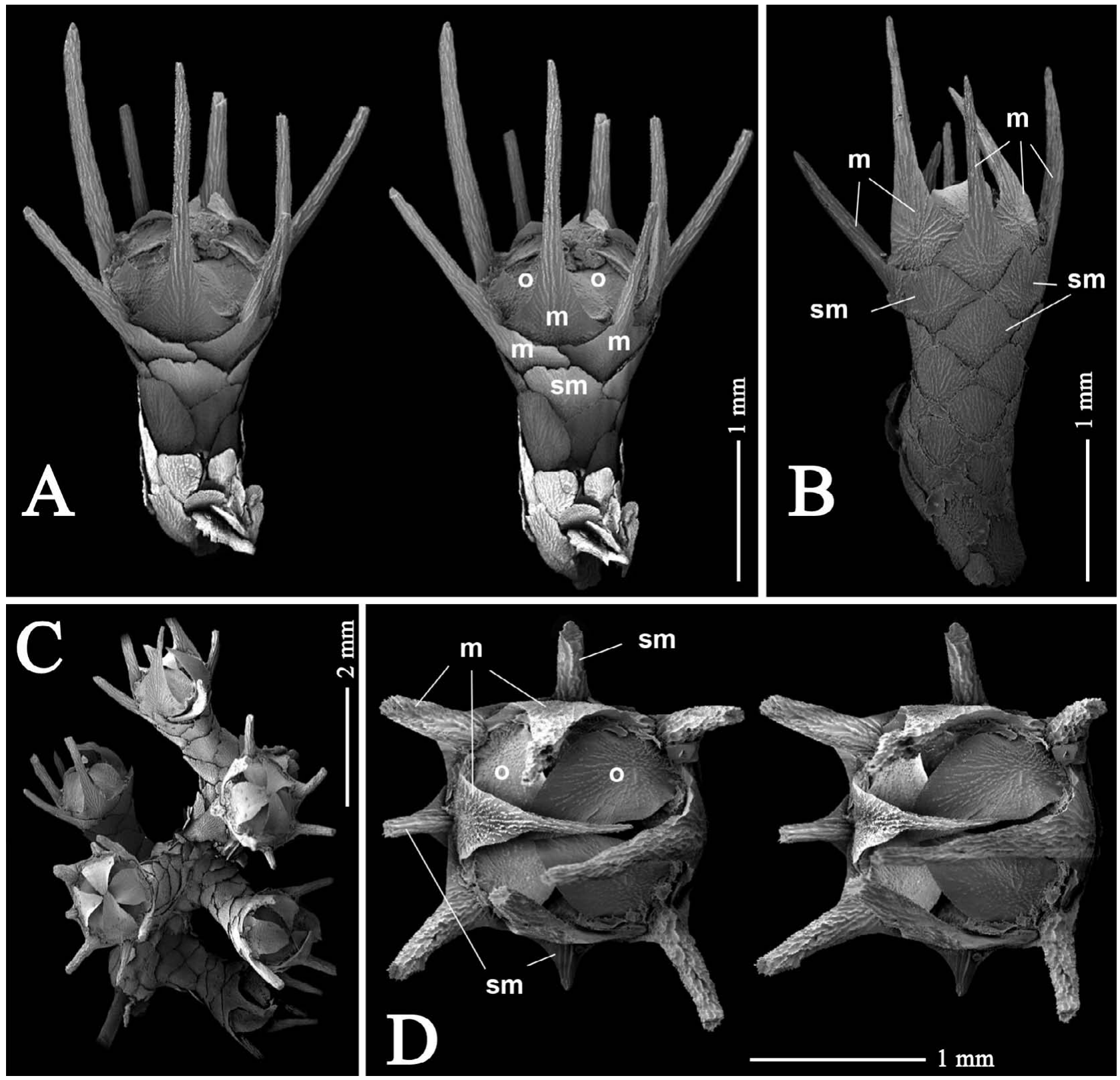

FIG. 5. - Thouarella sardana n. sp., holotype ZIZMH C11740: A, polyps in adaxial view, stereo pair; B polyps in abaxial view; C, detail of branchlet; D, polyps in oral view, stereo pair. Abbreviations: o, opercular scales; m, marginal scales; sm, submarginal scales.

$2.1-3 \mathrm{~mm}$ in height and $0.74-0.93 \mathrm{~mm}$ in diameter without including submarginal thorns, which may extend considerably beyond the operculum. Polyp body with 7 longitudinal rows of scales, 5 transverse rows of scales on each longitudinal abaxial row overlapping one another.

Four to six accessory opercular scales (Fig. 6A), each small, higher than broad, and 0.41-0.61 x 0.16$0.23 \mathrm{~mm}$. Proximal half of inner surface tuberculate, smooth distally, without keel. Outer surface quite smooth. Basal margin with digitate processes, free margin finely serrated.
Opercular scales, 0.63-1.2 x 0.33-0.69 mm, arranged in two alternate cycles of four scales: inner cycle (Fig. 6B) with oval tips and square base; outer cycle (Fig. 6C) with isosceles-shaped scales. Inner surface as in accessory opercular scales; outer surface with radial granules from nucleus on proximal portion. Free margin finely serrated.

Marginal scales (Fig. D) seven to eight in number, basal part of scale equilateral triangleshaped projecting a high and nearly cylindrical thorn, $1.5-2.5 \times 0.63-0.91 \mathrm{~mm}$ (including thorn), thorn more than three-quarters of total sclerite 


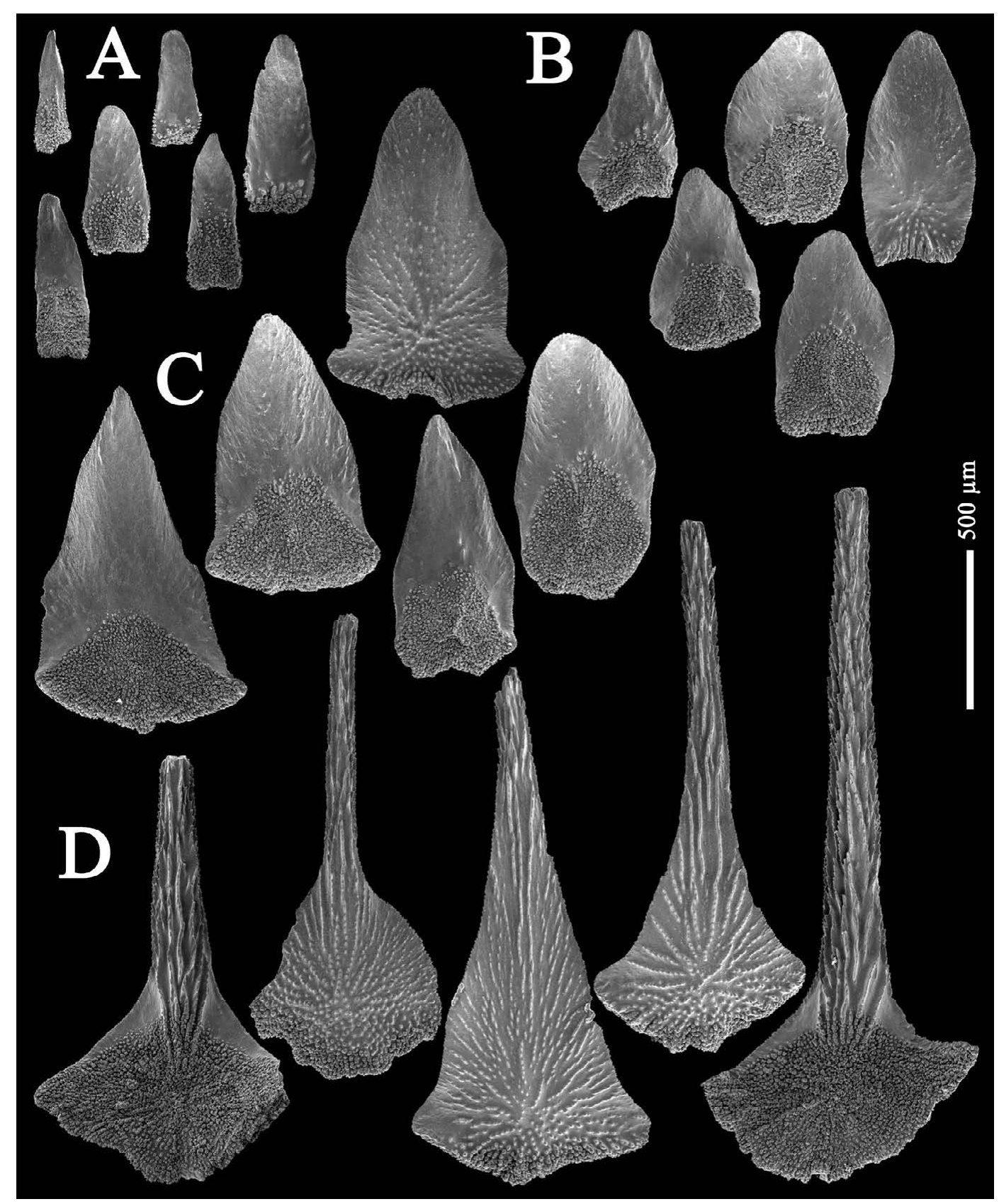

FIG. 6. - Thouarella sardana n. sp., holotype ZIZMH C11740: Accessory opercular scales (A). Opercular scales from inner (B) and outer (C) alternate cycle. Marginal scales (D).

length. Thorn with numerous longitudinal ridges on all sides. Inner surface tuberculate covering part of thorn base, with distal smooth areas. Outer surface with radial granules from nucleus on proximal portion. Free margin finely serrated, proximal margin with digitate processes.

Body wall scales (Fig. 7A) fan-shaped, with tendency to square or oval shape, $0.58-1.17 \mathrm{~mm}$ in maximum length. Inner surface completely tuberculate, outer surface covered with radial, often pointed granules from nucleus on proximal portion. Free margin finely serrated, basal margin with digitate processes. Distalmost cycle (below submarginal one) with or without distal thorn (see Fig. 5A, B for scales without thorn and Fig. 5D for scales with thorn).

Coenenchyme scales (Fig. 7B) more diverseshaped from circular to irregular elongated polygons, $0.22-0.8 \mathrm{~mm}$ in maximum length. Surface with similar characteristics to body scales. Margin from quite smooth to with digitate processes. 


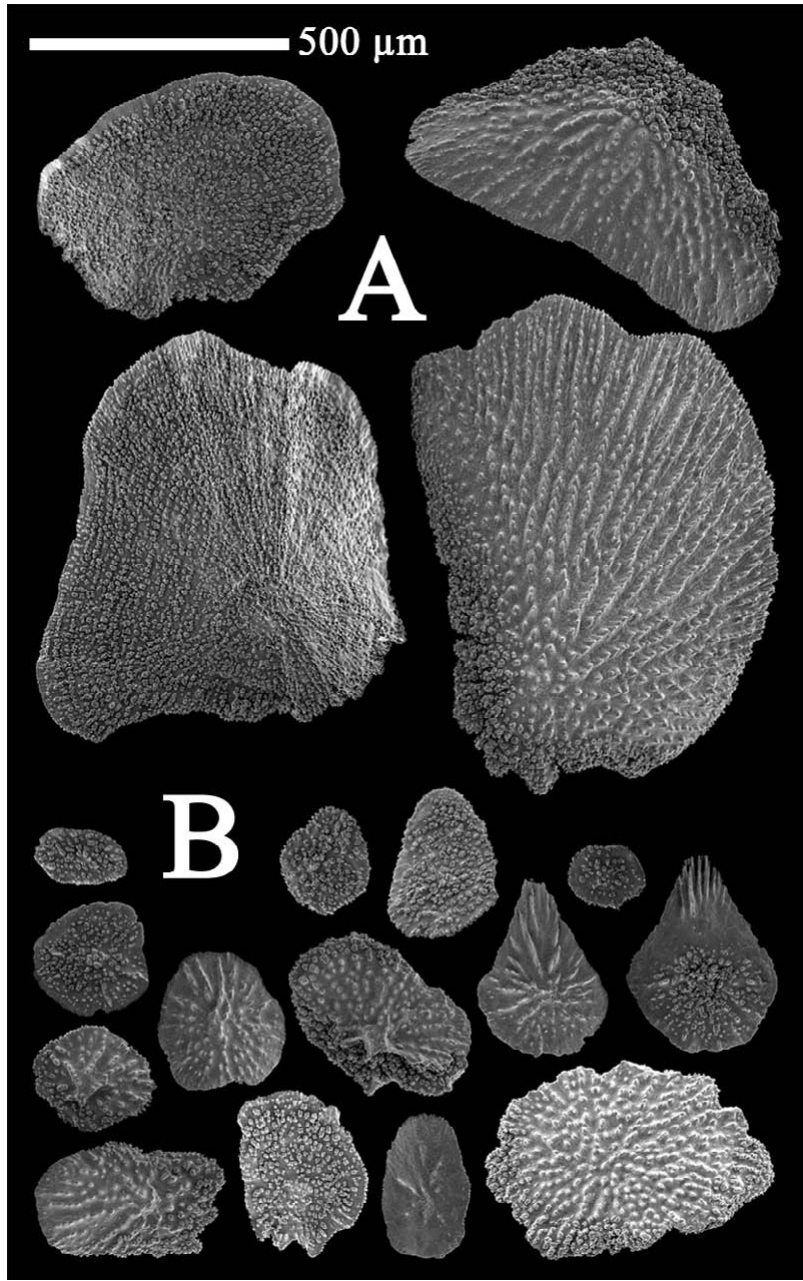

FIG. 7. - Thouarella sardana $\mathrm{n}$. sp., holotype ZIZMH C11740: Body scales (A); Coenenchymal scales (B).

Variations. The general colonial structure of the paratypes and additional examined material is quite similar to that of the holotype. The colonies have the base attached to a hard substrate by a white, calcareous, discoidal holdfast. The basal portion of the colony, first $3-11 \mathrm{~mm}$, is devoid of branchlets. The colonies only show one main stem and a variable number of branchlets, the size of the colonial fragments varying from 4 to $14.5 \mathrm{~cm}$ in height and from 2.5 to $5 \mathrm{~cm}$ in width. The branchlets of some fragments are bent towards one side. The polyps are slightly shorter than in the holotype, 1.2-1.5 mm. The accessory opercular scales can vary from 3 to 6 (usually more than 4 ) in number. The distribution and the form of the sclerites from polyps and coenenchymes are as in the holotype.

Geographic and bathymetric distribution. At present, Thouarella sardana n. sp. is only known from South Georgia Island area, Antarctica (Fig. 1), between 278 and $434 \mathrm{~m}$ in depth.

Etymology. The species name is derived from a type of circular dance typical of Catalonia, called Sardana, as the arrangement of thorny submarginal scales resembles the dancers holding hands and raising them in the air.

\section{Thouarella (Thouarella) undulata $\mathrm{n} . \mathrm{sp}$.} (Figs. 8A-B, 9-10)

Examined material. Holotype: ZIZMH C11742, ANT XIX/5, stn PS61/167-01, 53 ${ }^{\circ} 23.68^{\prime}$ S, $42^{\circ} 42.23^{\prime} \mathrm{W}$, west of South Georgia, Antarctica, 306.0 to $342.7 \mathrm{~m}$ depth, 9 April 2002. Paratypes: ZIZMH C11743, with the same sampling data as the holotype, two colonies and 12 fragments. USNM 1123421, with the same sampling data as the holotype, two colonies (one of them without holdfast). Additional material: BEIM CRO-025, ANT XIX/5, stn PS61/167-01, $53^{\circ} 23.68^{\prime} \mathrm{S}, 42^{\circ} 42.23^{\prime} \mathrm{W}$, west of South Georgia, Antarctica, 306.0 to $342.7 \mathrm{~m}$ depth, 9 April 2002,one colony. BEIM CRO-026, ANT XIX/5, stn PS61/160-01, 532 $23.75^{\prime}$ 'S, $44^{\circ} 45.12^{\prime}$ W west of South Georgia, Antarctica, 434 m depth, 9 April 2002, one fragment. BEIM CRO-027, ANT XIX/5, stn PS61/164-01, 5323.80'S, 42 42.03'W, west of South Georgia, Antarctica, 312.5 to $321.6 \mathrm{~m}$ depth, 9 April 2002, three colonies and 13 fragments.

Description of the holotype. Colony bottlebrush (Fig. 8A), $10.1 \mathrm{~cm}$ in height and $3.3 \mathrm{~cm}$ in width without holdfast, probably part of a larger colony; branchlets stiff, bifurcate on their base, about 1.2-2.7 $\mathrm{cm}$ in length. Axis bronze in colour, stiff, basal axis diameter of $1.12 \mathrm{~mm}$.

Polyps almost perpendicular to stem (Fig. 8B), singly placed, present on main stem and branchlets, occasionally opposite on proximal part of branches, but without tendency toward pairs or whorls, 10-11 polyps per cm. Polyps (Fig. 9) relatively short, cylindrical to club-shaped distally; about $1.7-2.4 \mathrm{~mm}$ in height and $0.51-0.65 \mathrm{~mm}$ in diameter without including thorns from marginal scales, which may extend considerably beyond the operculum. Polyp body with seven longitudinal rows of scales, five scales on each longitudinal abaxial row overlapping one another.

Opercular scales in numbers of eight, arranged in two alternate cycles of four scales: inner cycle (Fig. 10A) small, 0.24-0.50 x 0.11-0.33 mm, with oval tips; outer cycle (Fig. 10B) larger, 0.51-0.69 x $0.36-0.53 \mathrm{~mm}$, bell-shape scales with convex inner distal surface. Proximal half of inner surface tuberculate, distal inner surface smooth, without keels. Outer surface with smooth granules radiating from nucleus. Basal margin with digitate processes, free margin quite straight. Scales distinctly undulate medially, more pronounced in the outer cycle. 


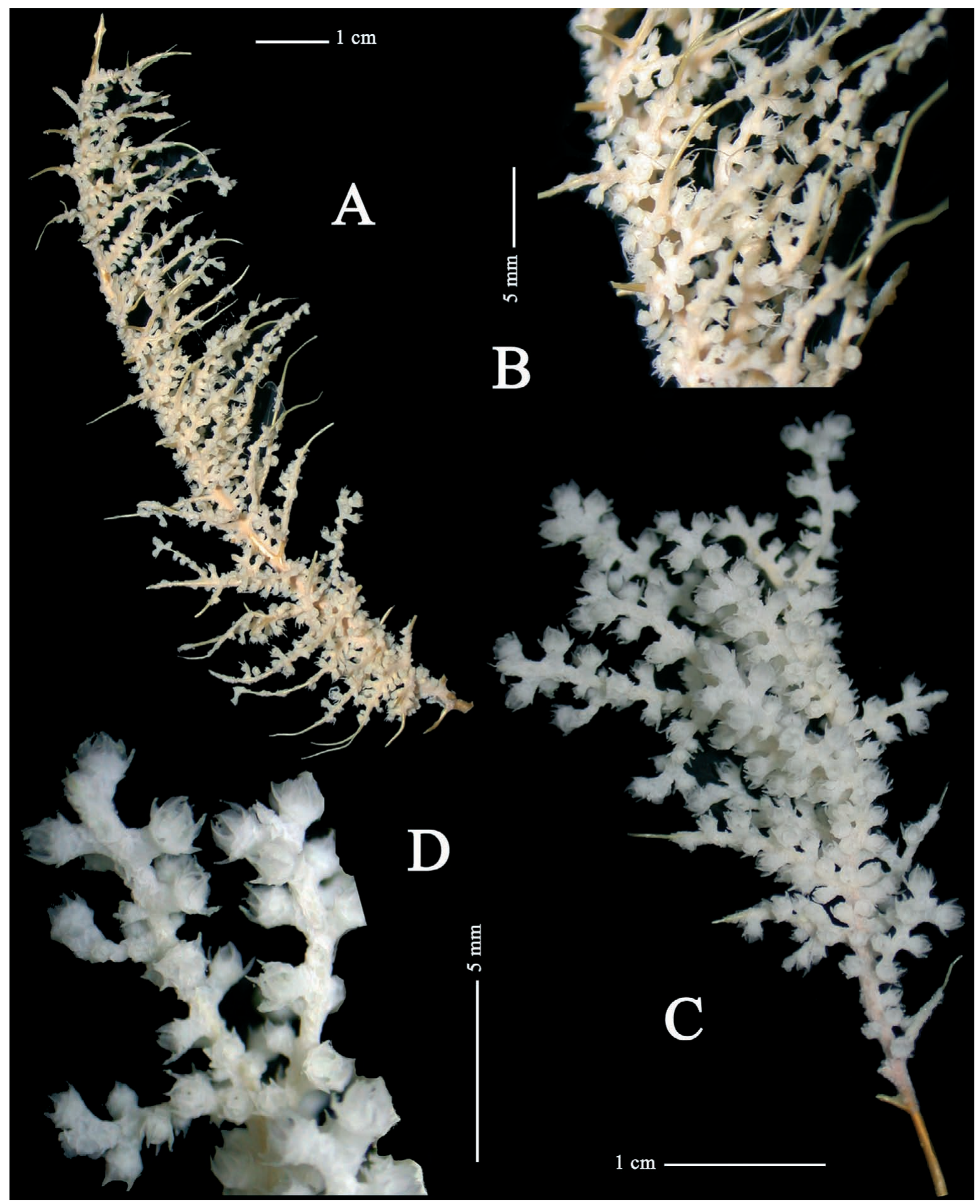

FIG. 8. - Thouarella undulata n. sp., holotype ZIZMH C11742: A, whole colony; B, detail of a branchlet. Thouarella andeep $\mathrm{n}$. sp. , holotype ZIZMH C11744: C, whole colony; D, detail of a branchlet.

Marginal scales (Fig. 10C), eight in number, arranged in two alternate cycles of four scales. Basal part of scale obtuse triangle-shaped projecting a high thorn nearly round in section, $0.69-1.47 \times 0.53-0.70 \mathrm{~mm}$ (including thorn), thorn $64-80 \%$ of total sclerite length. Thorn with numerous longitudinal ridges on all sides.
Inner surface tuberculate, covering part of thorn base, with distal smooth areas. Outer surface with smooth granules covering all scales. Free margin finely serrated, proximal margin with digitate processes.

Body scales (Fig. 10D), fan-shaped, with tendency to oval shape, $0.34-0.61 \mathrm{~mm}$ in diameter. 

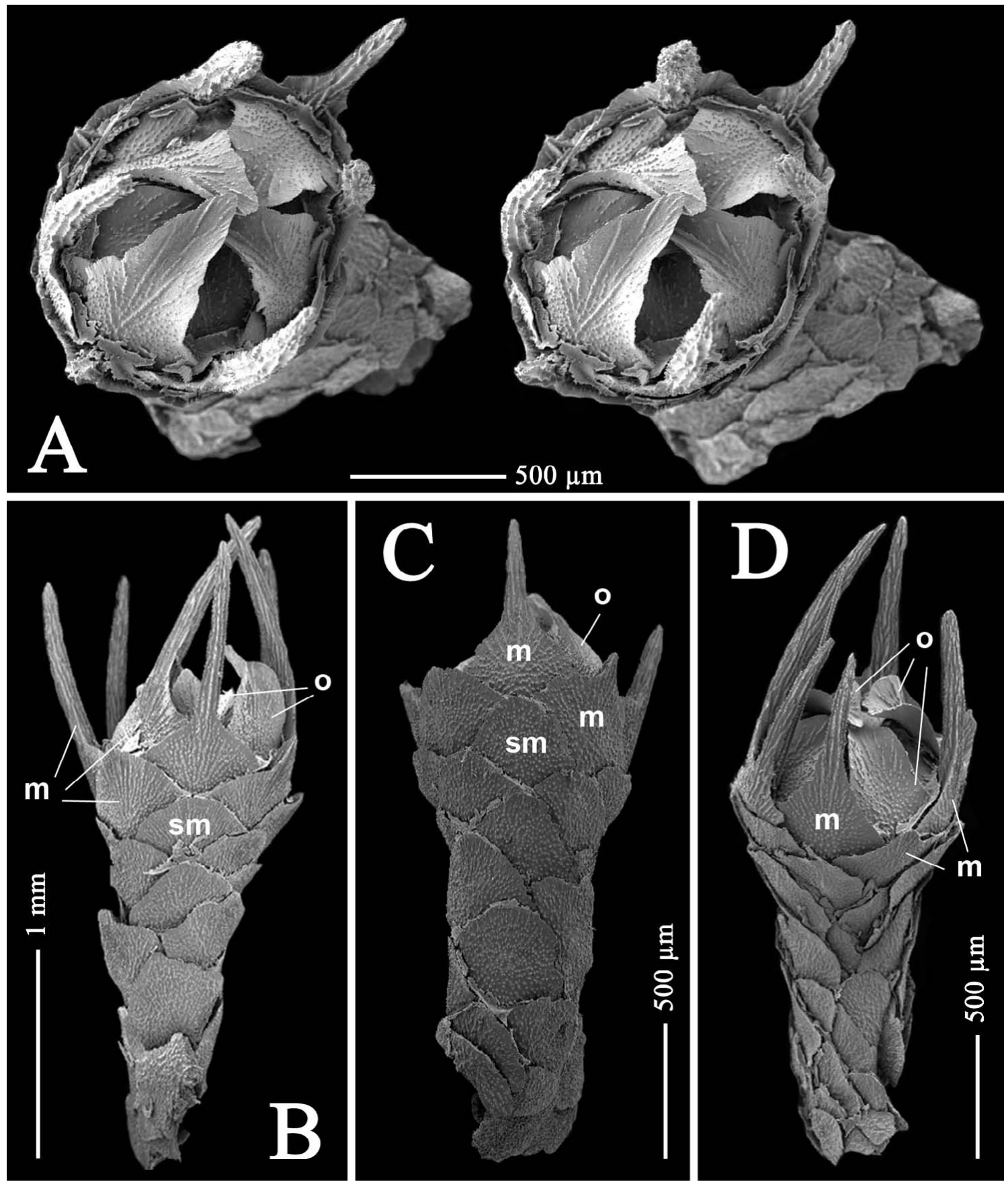

FIG. 9. - Thouarella undulata n. sp., holotype ZIZMH C11742: A, polyps in oral view, stereo pair; B, polyp in latero-adaxial view; C, polyp in abaxial view; D, polyp in adaxial view. Abbreviations: o, opercular scales; m, marginal scales; sm, submarginal scales.

Inner surface completely tuberculate, outer surface covered with smooth granules. Free margin finely serrated, basal margin with digitate processes.

Coenenchyme scales (Fig. 10E) more diverse shaped from circular to irregular elongated polygons, $0.12-0.46 \mathrm{~mm}$ in diameter. Surface with similar characteristics to body scales; some of them with radial ridges of granules distinctly elevated. Margin irregular due to presence of tubercles.
Variations. The general colonial structure of the paratypes and additional examined material is quite similar to that of the holotype. The colony fragments reach up to $11 \mathrm{~cm}$ in height and $5 \mathrm{~cm}$ in width. The colonies can show a base attached to a hard substrate by a white calcareous holdfast. Until the first appearance of branchlets, on stem there could be a range from $2 \mathrm{~mm}$ to $16 \mathrm{~mm}$ free of them. The polyp and sclerite form and distribution are as in the holotype. 


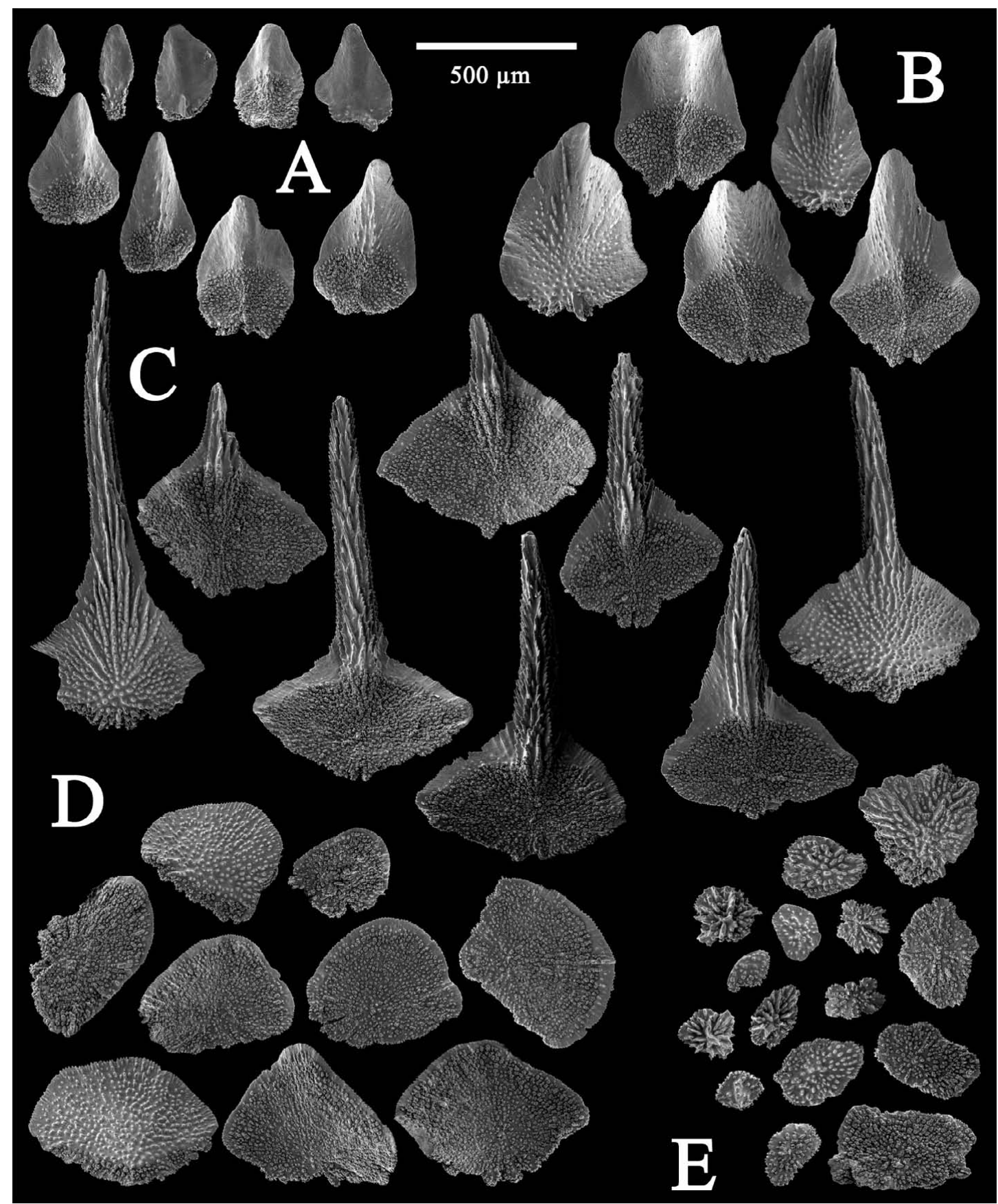

FIG. 10. - Thouarella undulata n. sp., holotype ZIZMH C11742: Opercular scales from inner (A) and outer (B) alternate cycle. Marginal scales (C). Body scales (D). Coenenchymal scales (E).

Geographic and bathymetric distribution. At present, Thouarella undulata n. sp. is known only from west of South Georgia Island, Antarctica (Fig. 1), between 306 and $434 \mathrm{~m}$ in depth.

Etymology. The species name is the feminine form of the Latin adjective undulatus, meaning undulate, in reference to the undulation of the tentacular scales.
Thouarella (Thouarella) andeep n. sp.

(Figs. 2C-D, 11-13)

Examined material. Holotype: ZIZMH C11744, ANT XIV/2, stn PS71/048-01, 70 $24^{\prime} \mathrm{S}, 08^{\circ} 19.72^{\prime} \mathrm{W}$, off Atka Bay, Antarctica, 601.8 $m$ depth, 12 January 2008. Paratypes: ZIZMH C11745, with the same sampling data as the holotype, two colonies. USNM 1123418, with the same sampling data as the holotype, two colonies. Additional material: BEIM CRO-028, CRO 43 and CRO44, ANT XIV/2, stn PS71/048-01, 70²4'S, 08¹9.72'W, off Atka Bay, Antarctica, $601.8 \mathrm{~m}$ depth, 12 January 2008 , four colonies. 

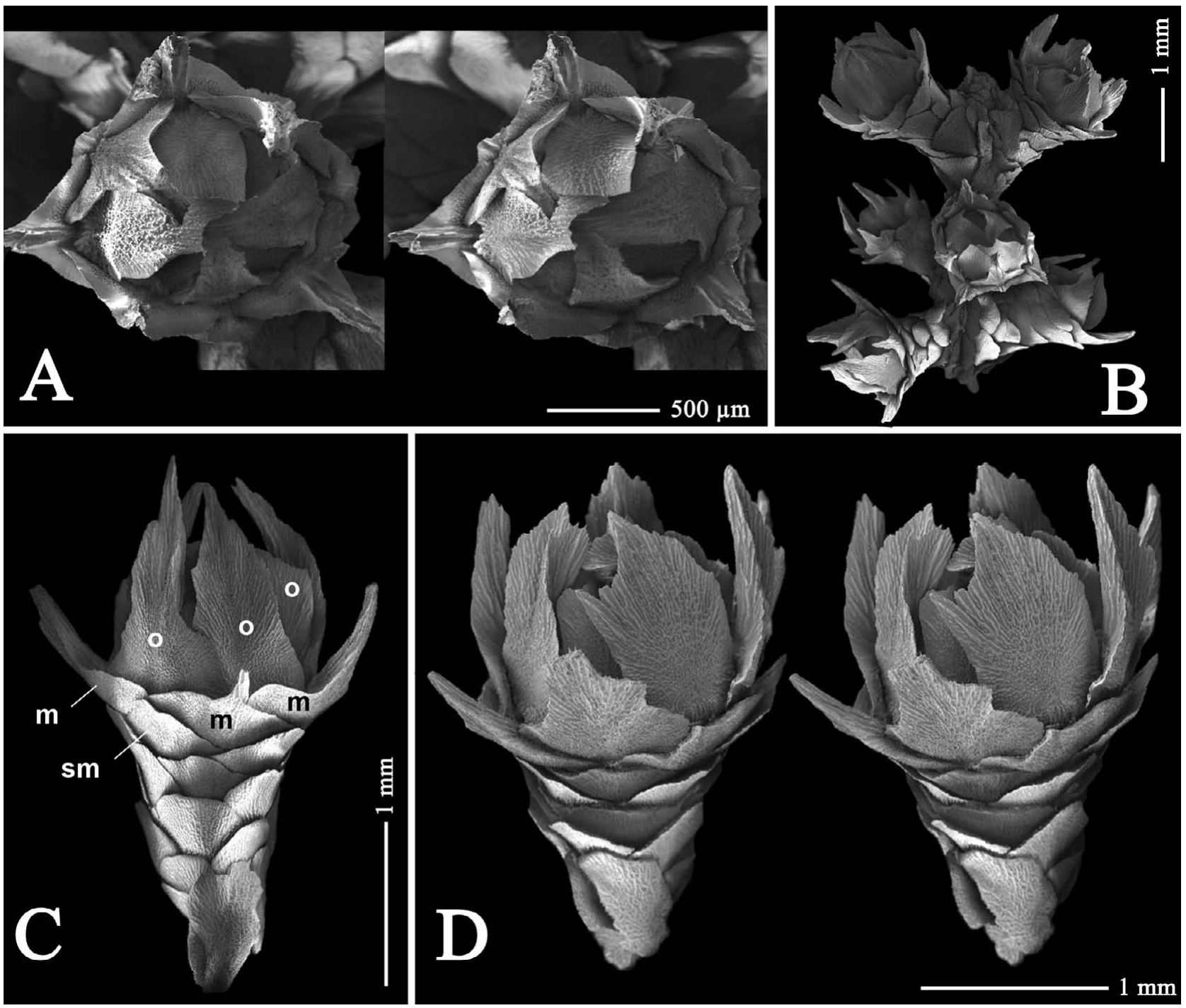

FIG. 11. - Thouarella andeep n. sp., holotype ZIZMH C11744: A, polyps in oral view, stereo pair; B, detail of branchlet; C, polyps in lateroabaxial view; D, polyps in adaxial view, stereo pair. Abbreviations: o, opercular scales; m, marginal scales; sm, submarginal scales.

Description of the holotype. Fragment of a bottlebrush colony (Fig. 8C), without holdfast, $5.9 \mathrm{~cm}$ in height and $3.2 \mathrm{~cm}$ in width; branchlets stiff, in acute angles, simple or bifurcate on the base, bent towards one side, about 1-2.2 $\mathrm{mm}$ in length. Axis bronze in colour, stiff, basal axis diameter of $0.5 \mathrm{~mm}$, and $11 \mathrm{~mm}$ height until the first branchlets. Colour of colony light pink.

Polyps almost perpendicular to stem (Fig. 8D), singly placed, present on main stem and branchlets, arranged in a spiral, with no tendency toward pairs or whorls, in clumps on branchlet tips, 10-11 polyps per $\mathrm{cm}$. Polyps (Fig. 11B) relatively short, club-shaped; about 1.9-3.4 $\mathrm{mm}$ in height and $0.70-0.95 \mathrm{~mm}$ in diameter. Polyp body with 7 longitudinal rows of scales, 4-5 scales on each longitudinal abaxial row overlapping one another.
Accessory opercular scales (Fig. 12A) in numbers of five-six, small, higher than broad, 0.24-0.42 x 0.07-0.30 mm. Proximal half of inner surface tuberculate, distal inner surface smooth, without keel. Outer surface quite smooth. Basal margin with a notch medially, free margin smooth.

Opercular scales, 0.51-1.1 x 0.34-0.52 mm, arranged in two alternate cycles of four scales: inner cycle (Fig. 12B) with rounded tips and square base. Inner surface like that in accessory opercular scales; outer surface with radial granules from nucleus on proximal portion. Free margin quite straight. Outer cycle (Fig. 12C) elongated distinctly concave longitudinally, with rhombus-base-shape and truncated or pointed tips. Proximal half of inner surface tuberculate, distal inner surface with longitudinal ridges, 


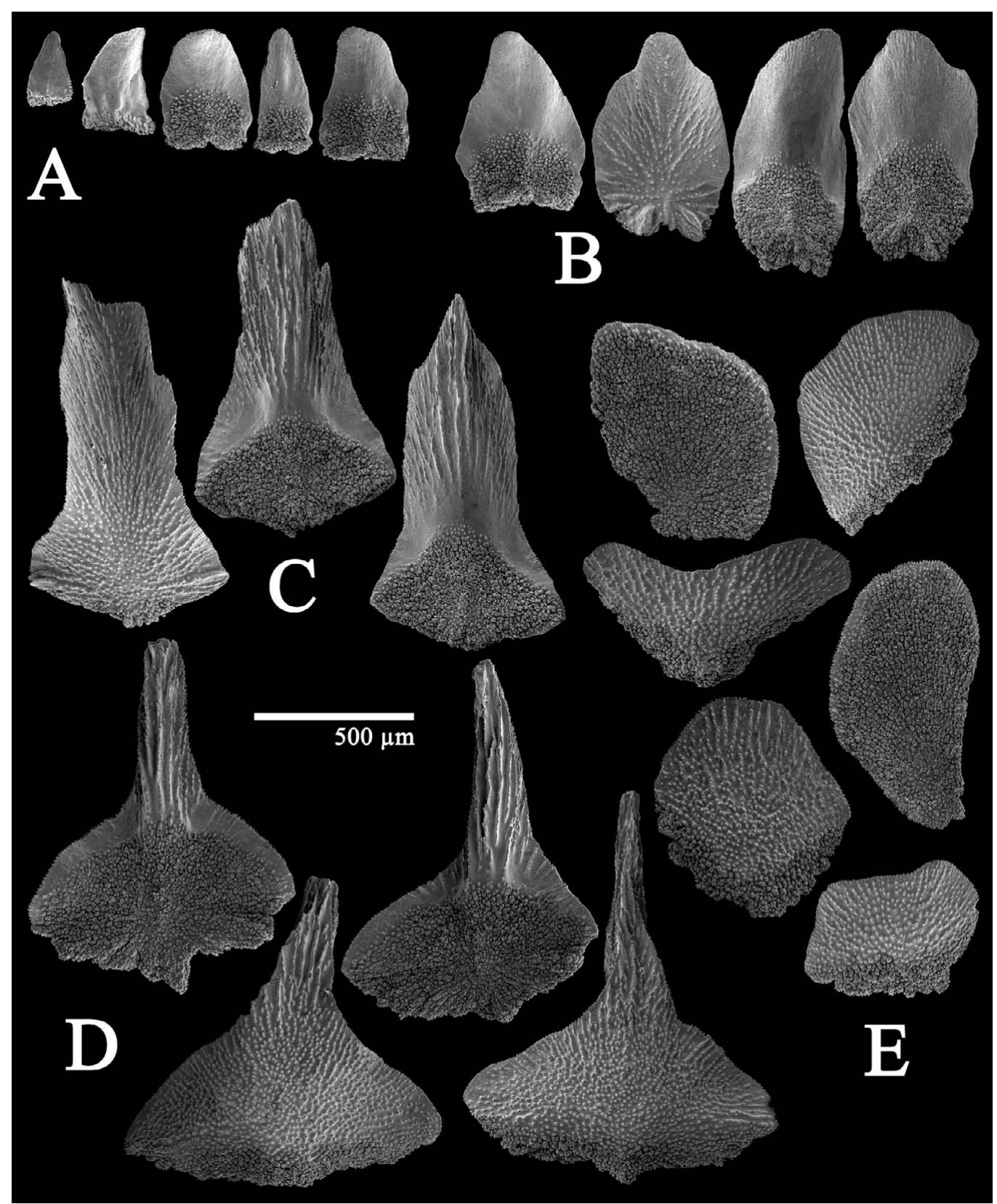

FIG. 12. - Thouarella andeep n. sp., holotype ZIZMH C11744: Accessory opercular scales (A). Opercular scales from inner (B) and outer (C) alternate cycle. Marginal scales (D). Body scales (E).

without becoming a distinct keel; outer surface with radial smooth granules from nucleus on proximal portion. Free margin finely serrated.

Marginal scales (Fig. 12D) eight in number, basal part of scale diamond-shaped, 0.95-1.32 x 0.74-0.99 $\mathrm{mm}$ (including thorn), thorn about two third (or less) of total sclerite length. Thorn with numerous longitudinal ridges on all sides. Inner surface tuberculate covering part of thorn base, with distal smooth areas. Outer surface covered totally by granules. Free margin finely serrated, proximal margin with digitate processes.
Body scales (Fig. 12E), fan-shaped, with tendency to square or oval shape, $0.54-0.84 \mathrm{~mm}$ in maximum length. Inner surface completely tuberculate, outer surface covered with smooth granules. Free margin finely serrated, basal margin with digitate processes.

Coenenchyme scales (Fig. 13) more diverse in shape, from circular to irregular elongated ovals, $0.16-0.93 \mathrm{~mm}$ in maximum length. Surface with similar characteristics to body scales. In some scales granules as prominent wrinkle-like. Margin finely serrated, irregular with warts proximally. 


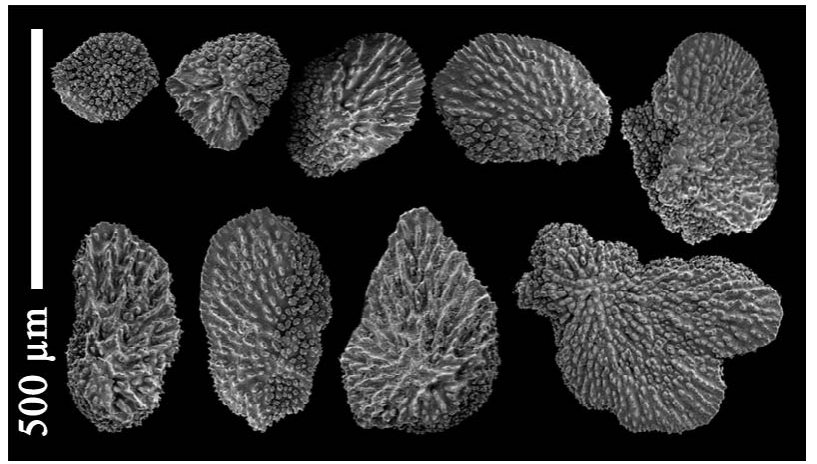

FIG. 13. - Thouarella andeep n. sp., holotype ZIZMH C11744: Coenenchymal scales.

Variations. The general colonial structure of the paratypes and additional examined material is quite similar to that of the holotype. Colonies are more flattened in shape, from 3 to $8.5 \mathrm{~cm}$ in height and from 3 to $5.6 \mathrm{~cm}$ in width. Branchlets reaching up to $2.8 \mathrm{~cm}$ in length. Colonies do not present a holdfast like the holotype. The number of polyps per centimetre can reach up to 12 on branchlets. The polyp and sclerite form and distribution are as in the holotype. Accessory opercular scales are small from 3 to 8 (usually 4) in number.

Geographic and bathymetric distribution. At present, Thouarella andeep $\mathrm{n}$. sp. is known only from off Atka Bay, Antarctica (Fig. 1), $601.8 \mathrm{~m}$ in depth.

Etymology. The species name is dedicated to people belonging to the project Andeep-Systco, as thanks to their insistence we finally had an extra station, which was the locality where the new species was found. Name considered as a noun in apposition.

\section{DISCUSSION}

\section{Remarks on the subgenus}

All the new species described above have thorny marginal scales, and lack this distal projection in the opercular ones. From a morphological point of view, and according to subgenera differentiations given by Kükenthal $(1915,1919,1924)$ and subsequent authors (Cairns and Bayer, 2009), these species should be included in the subgenus Thouarella due to the presence of thorns on the marginal scales and the single distribution of polyps on branchlets.

In three of the species here described (T. bayeri $\mathrm{n}$. sp., T. sardana n. sp., and T. andeep n. sp.), there are additional sclerites (in one or two cycles, here named accessory opercular scales) distal to opercular scales, up to two cycles in T. bayeri n. sp., but only one (usually incomplete) in the other two species. Due to their minute sizes it may be possible that these additional cycles are present in other, already described species of Thouarella. Kinoshita (1908:5), in describing T. hilgendorfi Studer, illustrated in Figure 1 four of the eight scales in each cycle of the distal transverse rows. Morphologically his circumopercular scales (rows IV and III in his figure) seem to correspond to the marginals (row IV) and operculars (row III), while his operculars (rows I and II) seem to correspond to the accessory opercular scales found in some of the new species described herein. After Kinoshita (1908), in T. hilgendorfi the inner row of his opercular scales (row I) is composed by very reduced and even absent sclerites, as in new species described above, in which the accessory opercular scales could not be found in complete cycles. This could mean a reduction (rather than a gain) in the number (and sometimes probably in cycles) of scales through the internal evolution of the group. This feature, in combination with a molecular approach, when possible, can modify ranges of variability and can improve our understanding of the evolution of primnoid gorgonians.

\section{Comparison of the new species with other congeners}

Within the subgenus Thouarella, T. bayeri n. sp., due to its uniplanar colony shape, is only comparable with T. bipinnata Cairns, 2006. However, both are distinguishable by their polyp scales (see Fig. 9 in Cairns, 2006 and Fig. 4 in this paper). Thouarella bipinnata shows a prominent keel in opercular and marginal scales which are about the same height, while in $T$. bayeri $\mathrm{n}$. sp. keels are absent in both marginals and operculars, the former scales being much more similar to those in T. diadema (see Cairns, 2006: fig. 11, and Fig. 4 of this paper), so marginals and operculars show a remarkable difference in size and proportions in the new species. The presence of the accessory opercular scales in T. bayeri $\mathrm{n}$. sp., also distinguishes this species from T. bipinnata. Finally, T. bipinnata shows a lateral uniplanar branching pattern, while in the new species this pattern is clearly dichotomous. Although the uniplanar colony shape is also present in some species of the subgenus Euthouarella, the arrangement of polyps differs, being singly in T. bayeri n. sp. and in pairs or whorls in subgenus Euthouarella. 
Thouarella sardana n. sp., T. undulata $\mathrm{n}$. sp. and $T$. andeep $\mathrm{n}$. sp. have in common the following set of characters: bottlebrush colony shape and lack of keel on opercular scales. Both characters are also present in Thouarella diadema, and were used by the original author to distinguish this last species from its subgeneric partners.

The opercular scales of T. undulata n. sp. and $T$. diadema are distinguished by their concave appearance in the former. Although marginal scales of both species show a prominent thorn, the tuberculate surface on the inner surface differs: while in T. diadema the basal part of the thorn is mainly free of tubercles, in T. undulata $\mathrm{n}$. sp. this area is practically covered.

Thouarella sardana $\mathrm{n}$. sp. and T. andeep $\mathrm{n}$. sp., although not complete, present an accessory opercular scales cycle, being absent in $T$. diadema and $T$. undulata $\mathrm{n}$. sp.

In addition to the above-mentioned difference, Thouarella sardana $\mathrm{n}$. sp. clearly differs from $T$. undulata $\mathrm{n}$. sp. in the presence in the latter of a surface that is distinctly undulate medially in opercular scales, whereas it is nearly flat in $T$. sardana n. sp. The latter species also shows (like T. undulata $\mathrm{n}$. sp.) the basal part of the thorn in marginal scales practically covered by tubercles, while in $T$. diadema this area is almost free of them.

In the case of Thouarella andeep $\mathrm{n}$. sp., marginal scales show a thorn not as prominent as in $T$. undulata n. sp. or in T. diadema. Furthermore, opercular scales in T. andeep n. sp. are distinctly concave longitudinally and have an obtuse triangle-base-shape; these features also distinguish this species (T. andeep n. sp.) from T. undulata n. sp. and T. diadema.

Thouarella sardana $\mathrm{n}$. sp. and T. andeep n. sp. are differentiated from each other by the shape and ornamentation of their opercular and marginal scales. On the one hand, opercular scales of T. sardana $\mathrm{n}$. sp. are isosceles triangle-shaped and their inner surface is quite smooth distally, whereas in $T$. andeep $\mathrm{n}$. $\mathrm{sp}$. the inner and outer cycle of four corresponding with the operculars are clearly different: the outer scales are elongated with longitudinal crests, with the distal part concave-tubular. On the other hand, the marginal scales of $T$. sardana $n$. sp. have a prominent thorn, the bases are equilateral triangle-shaped and their outer surface is covered by granules arranged radially from the nucleus, while the scales in $T$. andeep $\mathrm{n}$. sp. have a less prominent thorn, the bases are more oblong-shaped, and they have a surface almost covered by granules without any clear arrangement.

\section{ACKNOWLEDGEMENTS}

The authors acknowledge the valuable assistance of the officers and crew of the RV Polarstern, and many colleagues on board during the LAMPOS and ANDEEP-SYSTCO cruises. We take this opportunity to extend our thanks to the cruise leaders and steering committee of the cruises (especially Wolf E. Arntz in LAMPOS and Uli Bathmann and Angelika Brandt in ANDEEP-SYSTCO), who kindly facilitated the work on board and provided the opportunity to collaborate in these Antarctic programmes. Special thanks are addressed to some friends and colleagues for their valuable assistance during the LAMPOS (Neus Vert and Estefanía Rodríguez), and ANDEEP-SYSTCO (Michi Schrödl, Enrico Schwabe and Laura Wuerzberg) cruises. The authors are also thankful for comments and suggestions given by the Editor and the anonymous referees. Support for this work was provided by the Spanish CICYT projects REN2001-4929-E/ ANT (LAMPOS) and POL2006-06399/CGL (CLIMANT). Mr. Tony Krupa is thanked for reviewing the English version. This is ANDEEP publication number 123.

\section{REFERENCES}

Alderslade, P. - 1998. Revisionary systematics in the gorgonian family Isididae, with description of numerous new taxa (Coelenterata, Octocorallia). Rec. W. Aust. Mus., 55:1-359.

Bayer, F.M. and J. Stefani. - 1989. Primnoidae (Gorgonacea) de Nouvelle-Calédonie. Bull. Mus. Natn. Hist. nat., Paris, (4) 10(A)3:449-476.

Bayer, F.M., M. Grasshoff and J. Verseveldt. - 1983. Illustrated trilingual glossary of morphological and anatomical terms applied to Octocorallia. E.J. Brill/Dr. W. Backhuys, Leiden, 1-75.

Cairns, S.D. - 2006. Studies on western Atlantic Octocorallia (Coelenterata: Anthozoa). Part 6: The genera Primnoella Gray, 1858; Thouarella Gray, 1870; Dasystenella Versluys, 1906. Proc. Biol. Soc. Wash., 119(2): 161-194.

Cairns, S.D. and F.M. Bayer. - 2009. A Generic Revision and Phylogenetic Analysis of the Primnoidae. Smithson. Contrib. Zool., 629: 1-79.

Kinoshita, K. - 1908. Primnoidae von Japan. J. College Sci., Imperial Univ. Tokyo, 23(12): 1-74.

Kükenthal, W. - 1915. System und Stammesgeschichte der Primnoidae. Zool. Anz., 46(5): 142-158.

Kükenthal, W. - 1919. Gorgonaria. Wiss. Ergebn. Dtsch. TiefseeExped. "Valdivia", 13(2): 1-946.

Kükenthal, W. - 1924. Gorgonaria. Das Tierreich.

Scient. ed.: M.P. Olivar.

Received January 28, 2009. Accepted April 21, 2009.

Published online November 30, 2009.

Note in proofs: Recent research on the type material of Thouarella diadema shows the presence of accessory opercular scales (Taylor, pers. comm.). The current definitions of the genus Thouarella and Plumarella are vague and unstable. The limits for those genera will be done in the near future, and some species now considered in the former genus could be transferred to the second one (Taylor, pers. comm.). 